\title{
PEASANTRY AS THE MAIN MILITARY FORCE DURING UKRAINIAN REVOLUTION PERIOD 1917-1921 ${ }^{1}$
}

\section{Masnenko V. V.}

\section{INTRODUCTION}

The modern period was the time of social transformations of the humanity. The main tendency was the demolition of traditional society in all aspects of being. Another feature was the mass character of political life (alongside with the development of parliamentary system and mass political parties). The social roles and behaviors of different social layers changed as well. The emancipation of peasantry, in its broader meaning, was one of the leading tendencies of the general process of modernization. The determining factor that accelerated this process was the emerging of mass army with the mechanism of conscription. In agrarian societies the peasantry was the main component of military service.

Ukrainian peasantry in Russian empire was a latecomer to this modernization process. However, it only slowed down its emancipation and it accelerated only during the World War I and the following revolutionary events.

The aim is to investigate the peculiarities of Ukrainian peasantry militarization that determined its leading role in the events of Ukrainian revolution 1917-1921, including the participation in regular armies, rebellion movement and peasantry war.

\section{During the World War I}

The World War I was the turning point of the modernization. Millions of peasants were torn apart from their traditional agrarian lifestyle and peasant world; they lost the connection with their usual way of keeping the household. Such a drastic catastrophic event could not but substantially transform the peasant's outlook. Researchers have already noticed the peculiarities of this process. For instance, Russian historian O. Gordon stated, that the peasantry at war radically and profoundly tears all the links with the previous, the peasant lifestyle and it cannot return to it. In overall, the war destroys the very essence of the peasants' outlook - the cyclical world perception, the established routine, the belonging to the "soil", etc, thus, the war triggered the mass "de-peasantation". If a peasant became a

\footnotetext{
${ }^{1}$ Publication contains the results of studies conducted on the implementation of the state budget theme «The Ukrainian Revolution (1917-1921): the peasant factor» (№ 0118U003864)
} 
revolutionary, there was no way back for him ${ }^{2}$. The last statement requires some correction, taking into account the fact, that the peasant-soldier during revolution did come back, but he was a different person - the one that responds to extreme challenges with radical actions.

Unprecedented death toll, the place of technology in mass homicide, the level of violence - all these factors influenced the mobilized army of peasantry even during the time of peace. As O. Porshneva claims, they were "on the other side" of moral and religious norms and prohibitions, which caused the changes in their perception of the boundaries of allowed violence, the value of human life, the significance of religious faith ${ }^{3}$. We can agree with V. Lozovyi that in military circumstances a full reevaluation of moral basics and religious values from Christian principle "Do not kill" to the military imperative: "Kill the enemy" took place. Marauder robbery of the civil population on the conquered territories was acceptable without saying. The basic assumptions of peasants about sins, the fear of God and other people were destroyed as well ${ }^{4}$.

On the other hand, even in new military conditions the peasantry still preserved some solely rural peculiarities of the world perception. As O. Mykhailiuk states: "The peasantry strived for localization, destruction of any authority that was higher than the local one, which objectively led to archaizing of the social life and excluded any statehood. Thus, the ideas and actions of the peasantry were incompatible with the policies of almost all state and political units".

The immediate participation of peasantry in violent actions led to the enforcement of psychological "setting" for cruelty in an enormous multimillion mass of people, the development of militarized consciousness, tendency for extreme violent actions, and devaluation of a human life. The Orthodox faith of peasants-soldiers, as O. Porshneva thinks, faced a serious outlook challenge during the war. As a result, Christian ethical norms and values were devaluated in the consciousness of masses, which prepared the ground for inherent (in the mentality of a traditional plowman) pagan beliefs, archaic mental stereotypes that in a bizarre way merged with rationalist principles that came from modernization and technical progress 5 .

\footnotetext{
2 Русское крестьянство и Первая мировая война : международный круглый стол / публ. П.П. Марчени, С.Ю. Разина. Новый исторический вестник. 2014. № 2 (40). С. 8-89.

${ }^{3}$ Поршнева О.С. Крестьяне, рабочие и солдаты России накануне и в годы Первой мировой войнь. Москва: РОССПЭН, 2004. С. 115.

4 Лозовий В. Солдати і дестабілізація суспільно-політичного становищ а: вплив Першої світової війни на революційні процеси в Україні (1917р.). Вісник Київського національного університету імені Тараса Шевченка. Історія. 2014. № 3 (121 ). С. 22.

${ }^{5}$ Поршнева О.С. Менталитет и сочиальное поведение рабочих, крестьян и солдат России в годы Первой мировой войны (1914 март 1918): Дисс. ... д-р ист. наук. Екатеринбург, 2000. 359 с.
} 
Thus, during the World war Ukrainian peasants in Russian army gained new socio-cultural features that contradicted their previous outlook. Obviously, not all of them became true warriors ("brave soldiers"). The long trench war, mostly, gave birth to the "grey soldier mass" that had only one aim - to survive in "bloody massacre". However, the majority of noncommissioned officers came from peasantry. They gained this title because of the personal bravery and innate wit. The future general of UPR army Mykola Kapustyanskyi characterized this category of military in the following way: "... "Khokhols", as they were called in the army, were needed in every detachment. Those were predominantly peasants, obedient, not spoiled, capable for soldiery and smart. A great percentage of them wanted to be Feldwebels and Wachmeisters" $"$

Another participant of war, and later - of revolutionary events, Nykyphir Avramenko also noted this peculiarity: "Ukrainians constituted the predominant percentage among non-commissioned officers, cavalry $i$ guard. Known by discipline and the feeling of duty..."7. We find similar characteristics in works of Oleksandr Udovychenko: "A Ukrainian soldier was always distinguished by his discipline, higher level of development and initiative. Thus, almost $40 \%$ of lower commanding positions were taken by Ukrainians, such as rojovyi (), chotovyi, bunchuzhnyi" ${ }^{8}$. Later, during revolution, these people had a special role of leaders of peasants' armed resistance.

In overall, the gained military experience facilitated the formation of the new type of peasants' consciousness - the one where the war and arms took the main place and the value of human life was significantly undermined".

\section{The beginning of revolution}

The next stage of peasantry militarization emerged on the ground of revolutionary events of 1917 . The general de-organization and demoralization of Russian army, de-sacralization of assumptions about the nature of autocratic authority and its demolition, the decline of authority of military commanding centre, the change of commanding functions by soldier committees accelerated the reformation of peasant-soldier's social role. From the sovereign of the emperor, he suddenly turned into "the master of his own destiny" who could impose his requirements not

\footnotetext{
${ }^{6}$ Капустянський М. Похід украӥнських армій на Київ-Одесу в 1919 роияі [в] Украӥна 1919 рік: М. Капустянський «Похід українських армій на Київ-Одесу в 1919 роичі». С. Маланюк «Уривки зі спогадів». Документи та матеріали. Документально-наукове видання. Київ : Темпора, 2004. С. 149.

${ }^{7}$ Авраменко Н. Спомини запорожия: Документальне видання. Київ : Темпора, 2007. С. 166.

8 Удовиченко О. Украӥна у війні за державність. Історія організації $і$ бойових дій Украӥнських збройних сил 1917-1921 рр. Вінніпег: Видав хорунжий УСС Дмитро Микитюк, 1954. С. 13.
} 
only on the former superior officers, but on any authority. As V. Lozovyi justly mentioned, the outlook and behavior of the soldier of the revolutionary period were determined by paradoxical combination of peasant values and militarized psychology of collective aggressiveness, gained during the war'.

The Ukrainization of military divisions of Russian army was also an important factor. On the one hand, this was an initiative of political activists (M. Mikhnovskyi, S. Petlura) and the engaged part of the military (activists of Pavlo Polubotok Ukrainian military club, Ukrainian military general committee, and delegates of All-Ukrainian military congresses).

On the other hand, Petrograd Temporary government and military commanding was forced to agree on the formation of Ukrainian national detachments. They were resistant to Bolshevik propaganda and ready for the call of duty. These detachments were the most effective during the military actions during the unsuccessful so-called "advance of Kerenskyi" during June-July of $1917^{10}$. The classical example of Ukrainized detachments is the $34^{\text {th }}$ army corpus under the command of P. Skoropadskyi, it was later renamed into the $1^{\text {st }}$ Ukrainian.

Undoubtedly, that the mass "Ukrainization of bugnet" facilitated the rise of national consciousness among the soldiers-peasants. At the same time, this process also increased their self-perception as of independent military force that can influence the nation-wide decision-making, especially concerning agrarian issue, important for the peasantry. Thus, the resolution of the Second All-Ukrainian military congress, where the soldiers-peasants constituted the majority of participants, supported the statements of the All-Ukrainian peasant congress on the agrarian issue. In such a way, an armed peasant became an important political factor in revolutionary events.

The all-rising revolutionary wave practically destroyed Western, Southern-Western and Romanian fronts against the countries of Quadruple Alliance. The almost chaotically demobilized at the end 1917 - at the begging of 1918 army filled the villages of Ukraine. The former soldiers became deserters; they owned an enormous quantity of weapons and military property. The peasants returned to their homes at least with guns and bullets and sometimes with machine guns and even with canons.

Apart from the "natural" self-arming, the peasants resorted to political actions. N. Makno in his memoirs described the actions of the anarchist Committee of the protection of revolution in August 1917 that

\footnotetext{
9 Лозовий В. Солдати і дестабілізація суспільно-політичного становищ а: вплив Першої світової війни на революційні процеси в Україні (1917 р.). С. 23.

10 Удовиченко О. Україна у війні за державність. Історія організації $і$ бойових дій Украӥнських збройних сил 1917-1921 рр. Київ : Україна, 1993. С. 15.
} 
implemented the seizure of weapons on the territory of Huliaipilshchyna from bourgeois estates and wealthy German colonies. The future leader of the biggest peasant army stated: "Thus, the weapons were taken away from bourgeoisie and distributed among the revolutionary peasantry. The seizure was implemented calmly, without casualties"11.

Before the Zvenyhorodskyi rebellion, the weapons collected by Yu. Tiutiunnyk - the one responsible for demobilization, was distributed from warehouses to peasants. During a few days and nights the rebels secretly distributed 10 thousand of guns, 43 machine guns, 2 canons, one ironclad warship and a lot of military equipment ${ }^{12}$.

Later, a huge amount of weapons was distributed among peasants during evacuation of German and Austrian-Hungarian armies from Ukraine. Revolutionized divisions voluntarily passed the weapons to Ukrainian rebels for the permission to leave for the homeland. Those few viable German divisions that left in Ukraine were also demilitarized. Thus, in February 1919, as a result of negotiations with counter-admiral von Kessler, the German divisions of Mykolaiv transferred all its weapons to rebels of ottoman Hryhoriev ${ }^{13}$.

These conditions formed new and at the same time contradictory social roles of "an armed peasant" - one part of peasants turned into marauders, another part formed free groups of self-defense.

\section{The rebellion movement and peasant war}

The following development of revolutionary events was marked by the rebellion movement that subsequently turned into a full-scale war.

The literature on the peasant rebellion movement ${ }^{14}$ represents different characteristics of its political orientation. Sometimes they are rather simplified. For example, the Russian researcher A. Kurenyshev while pointing on the versatile nature of the Ukrainian rebels and its peculiarities in each region, he still considered that these were "the left wings of Ukrainian socialist parties" that had an important role in its organization ${ }^{15}$.

However, M. Omelyanovych-Pavlenko provided a more detailed and appropriate characteristics of the rebellion movement as he distinguished the following four political directions: supporters of UPR, "Soviets",

\footnotetext{
${ }^{11}$ Махно Н. Воспоминания. Кн. 1. Русская революциия на Украине (от марта 1917 2. по апрель 1918 год). Париж 1929. С. 70.

12 Тютюнник Ю. Революційна стихія. Дзвін. 1991. № 8. С. 101.

${ }_{13}^{13}$ Вишнівський О. Повстанський рух і Отаманія. Збірник. Дітройт; Мічіген, 1973. С. 26.

14 Історіографія питання див. : Щербатюк B.M. Селянський повстанський рух в Украӥні 1917-1921 років: українська історіографія : автореф. дис. ... д-ра іст. наук 07.00.06. Київ : Київський нац. ун-т ім. Т.Г. Шевченка, 2013. 36 с.

15 Куренышев А.А. Крестьянские военно-политические организации России. Повстанчество. 1918-1922 г2. Москва 2010. С. 41.
} 
"plowmen" and "Makhnovists" (supporters of Makhno) ${ }^{16}$. Another peculiar feature was that these political convictions of rebellion leaders were rather unstable and could change depending on the current military and political situation. Regardless this versatility and instability, the observers of that time still noticed a general tendency in the development of peasants' selfrealization that determined the political direction of the rebels. Omelyanovych-Pavlenko also noticed that "after difficult alterations of the ideology of the people in 1919, it obtained a more stable statehood form. This ideology can be described by a truly prophetical statement: "In your home you have your truth, and power, and freedom". As a result, the fight on the East turns into the national struggle more and more" ${ }^{\text {". The only }}$ precaution to the abovementioned is that different participants of the struggle understood its sense in different ways (the variety of political beliefs was rather broad - from conservative statehood idea to the leftwing anarchist denial of it).

The turning point of the development of rebellion movement was peasants' protest at times of P. Skoropadskyi's Hetmanat. M. Kapustianskyi considered the short-sighted policy in agrarian issue the main catalyst of such a reaction, especially in areas where the owners, specifically "the Polish-didychi", tried to reimburse their loss by pressuring the peasants. "The confused peasantry turned to an armed resistance and self-protection from violence. The German did not understand the situation and the free-will spirit of our Ukrainian nation and started implementing terrible repressions, contributions and torture..."18.

On the other hand, modern authors, V. Lobodaev in particular, noticed, that free Cossack communities protested against the new authority since very first days. That new authority did not have time not only to implement, but even to declare its agrarian policy. Thus, the activism of the initiators of the protest is explained by their a priori rejection of a new authority as a reactionary one. At the beginning of May 1918 community meetings of different territorial levels declared anti-Hetman stance. On May the 3 delegates of Zvenyhorod povit peasant congress supported the decision to fight against the authorities immediately ${ }^{19}$.

In a month, on July 31918 the peasants from the village Orly of Lysyany volost Zvenyhorod powiat stood up against the forces of

\footnotetext{
${ }^{16}$ Омелянович-Павленко М. Спогади командарма (1917-1920): Документально-художнє видання / Упоряд.: М. Ковальчук. Київ: Темпора, 2007. С. 282.

${ }^{17}$ Там само. С. 280.

${ }^{18}$ Капустянський М. Похід українських армій на Київ-Одесу в 1919 роиі. С. 69.

19 Лободаєв В. Участь Вільного козацтва в селянському повстанському русі (травень - серпень 1918 р.). Вісник Прикарпатського університету. Історія. 2011. Вип. 20. С. 71.
} 
execution thus launching the Zvenyhorod uprising ${ }^{20}$. The crushing defeat of the force created favorable conditions for other rebellious actions. The uprising quickly spread to the neighboring Lysianka and the whole powiat. On the $5^{\text {th }}$ of July, the peasants from Moryntsi, Pedynivka, Vilshana got also engaged in a protest. The rebellious forces of 15 thousand people under Zvenyhorodka occupied the city on $9^{\text {th }}$ of July. The German divisions were defeated at Shpola, Tsvitkove and Talne.

The rebellions took place at Kaniv, Cherkasy and Tarashchan powiats. The citizens of Tarashchan established communication with several groups from Zvenyhorod, Uman, Vasylkiv, Skvyr, Kaniv and other powiats. Seeking for taking advantage, Zvenyhorod rebellion group tried to take the leadership and to lead the rebellion. However, they did not manage to do that, since the majority of peasants returned to their homes - to gather the harvest. That was another feature of the rebellion movement - local nature and dependence of the agrarian household cycle.

In July 1918 the rebels from Zvenyhorod and Tarashchan united: a new fight began. However, more outnumbering forces of the enemy made those rebels who did not surrender to retreat to the borders with Bolshevik Russia and cross the Dnipro to the left bank.

Katerynoslav region was the second area of the peasant rebellion movement in spring 1918. In May 1918 the rebels disarmed Austrian jager battalion in the village Lozovatka. The villagers from Mykhailivka, Oleksandrivka, Pokrovskyi also supported the uprising. However, the outnumbering forces of cavalry suppressed the uprising. Peasant groups under control of anarchists in Oleksandrivska region also provided an armed support to Red Army divisions that were retreating from German and UPR forces. From that time on we can observe the deployment of Makhno movement in its most massive form.

The launched peasant resistance was impossible to stop neither by local execution actions, nor by bigger repressive methods. The following escalation of revolutionary events with the constant change of geopolitical situation and the rise of warlike opposition led to the involvement of a great mass of peasants into the war actions. Firstly it was their active participation in successful battles of Directory versus Pavlo Skoropadskyi subdivisions. Later, with the further deployment of Bolshevik aggression in 1919, the appearance on the territory of Ukraine of the military forces of Antanta, the advance of Voluntary army and the armed forces of the South of Russia, the Polish armed groups, the rebellion movement became more permanent and massive.

${ }^{20}$ Щербатюк, В. М. Звенигородське збройне повстання. Краєзнавство Черкащчини. Черкаси 2005. Вип. 8. С. 136-149; Кульчицький Ю. Шаблі з плугів : Украӥнський повстанський рух у визвольних змаганнях [1917-1926 рр.]. Львів : Ін-т українознавства ім. І. Крип'якевича НАН України, 2000. 260 с. 
The peak of the deployment of the rebellion movement was in 1919 . But at the same time it acquired more destructive features. Nykyphir Avramenko mentioned: "The rebellion groups changed their National flag for a red one. "Everything is allowed!", "Rob what is already robbed!" mottos appeared to be more attractive. There were groups that seemed to stick to the national ideas, but they did not recognize any authority"... "It was a chaotic and disorganized force and it cared only about its village, volost and powiat. In the future they were all defeated. The "ottomans" did not think about what was coming next" ${ }^{21}$.

On the other hand, the power of the rebels was in this massiveness. As M. Omelyanovych-Pavlenko highlighted: "There was not a village in Ukraine that did not have its "commanding center" or a gathering point in a secret ravine or near the giant oak of "Mazepa". There they got rid of the accumulated energy at home and there the leaders-ottomans spread their opinion and will and formed the base for struggle" 22 .

The peasant rebellion movement was not limited only by revolution period, it gained momentum during Bolshevik occupation in 1920. Only concessions like NEP, Ukrainization and "exhaustion" of the peasantry resources led to the gradual suppression of rebellion in 1992-1923. The last events of the peasant war were the revolts against the compulsory collectivization and anti-peasant policy of Bolsheviks in Pavlohrad and Drabiv (1930) and the resistance against the policy of GenocideHolodomor (1932-1933).

\section{Ottoman and Makhno movements}

The phenomenon of the peasant rebellion movement cannot be understood without the analysis of such an important factor as Ottoman movement that determined the nature and essence of the peasant war. O. Vyshnivskyi divided the leaders of the rebels into two unequal groups the positive and negative (harmful) ottomans. Among the latter he mentioned the so-called "fathers-ottomans" that "either shined in glory, or were covered in shame and betrayal". As he claimed: "«Fathers-ottomans» and their groups were always labeled as adventurists and their negative actions were immediately associated with Ukrainian army and its Chief Ottoman" 23. The "spirit of the ottomania" was firstly noticed among irregular divisions of UPR army (the rebels), that joined the regular army during the uprising against Hetman Skoropadskyi. M. OmelyanovychPavlenko also noticed the emergence of ottamans-criminals that joined the

\footnotetext{
${ }^{21}$ Авраменко Н. Спомини запорожия: Документальне видання. С. 258.

${ }^{22}$ Омелянович-Павленко М. Спогади командарма (1917-1920). С. 281.

${ }^{23}$ Вишнівський О. Повстанський рух і Отаманія. Збірник. С. 10-11.
} 
trend of "organized hooliganism ... and the tendency of broader social groups, hurt by the long presence at war, for nomadic, full of everyday danger life" 24 .

Eventually, this "steppe freedom" gave birth to its most famous leader - ottoman Nestor Makhno that managed to become "the father of fathers". Peasant army of ottoman N. Makhno that was acting under mottos of non-recognition of any authority was the most powerful rebellious formation. V. Verstiuk thinks that the precise quantity of Makhno army is impossible to state.

On the peak of its activity in October-November 1919 the revolutionary rebellious army of Ukraine (supporters of Makno) possessed 40 thousand bugnets, 20 thousands of sabers, 1000 machine guns and 20 cannons - according to data of V. Bilash. Different sources and authors establish its quantity from 20 to 100 thousands soldiers ${ }^{25}$. The basis of Makhno rebellion movement was Steppe Left Bank: Katerynoslav, Kherson, Tavria powiats and the part of Donbas.

\section{The participation in regular formations}

The peasants constituted the main part of regular military formations that fought over the control on the territory of Ukraine. The majority of them were drafted. Thus, such "forced soldiers" changed armies 3-4 times ending up in some rebellious group.

The Acting Army of UPR had a typically peasant nature and it included different rebellion formations.

General M. Kapustianskyi claimed that rebellious forces of Directory in December 1918 included 300 thousand people (the number is obviously exaggerated the real number at the beginning of 1919 did not exceed 75 thousand -V.M.) mostly peasants. Though the draft was announced, the majority of peasants joined the army voluntarily as they hoped to demand the resolution of the agrarian issue. The majority of military groups emerged chaotically, "in revolutionary way". Those were weakly organized little tactical units led by almost illiterate in soldiery ottomans. In its essence it was the rebellious mass of peasants, "the most numerous elements but little reliable in struggle with Bolsheviks... The peasant uprising had mostly social reasons and only a part of it had national sentiments" 26 .

\footnotetext{
${ }^{24}$ Омелянович-Павленко М. Спогади командарма (1917-1920). С. 192.

${ }^{25}$ Верстюк В. Махновщина: Селянський повстанський рух на Украӥні (1918-1921). Київ: Наукова думка, 1991. С. 186.

${ }^{26}$ Капустянський М. Похід украӥнських армій на Київ-Одесу в 1919 роиі. С. 72-74. 
M. Omelyanovych-Pavlenko also mentions the so-called "peasant divisions" in Acting Army that were loyal only to their ottomans ${ }^{27}$. Komandarm gave a very precise characteristic for those formations. The traditional "ottoman law" based on unquestionable respect towards "single amateurs": "Just as Haidamaks, the peasant division (Kyiany (citizens of Kyiv)) was the irregular combination that only partially recognized the authority of UPR. Two months later these two groups ... engaged into a battle in the result of which one group was left with yellow-blue flag and the second one retreated already with the motto "Live the Soviet Ukraine!" to the hostile camp. This fact would be reverse for the peasant division: new elements would join it and start the transformation towards the regular division" 28 .

In April 1919 the reorganization of Acting army of UPR was implemented, in the result of which the quantity was reduced, but the combat ability increased. As M. Kapustianskyi observed, the natural selection was conducted and "All the adventurist and occasional did not bear the difficulties of the march and dispersed". "The ottomans disappeared, the groups dispersed, the drafted Cossacks (especially from the Left bank) went back home with guns, equipment and ammunition" 29 .

M. Omelyanovych-Pavlenko left interesting observations concerning the treatment of the peasantry of Uman and Cherkasy region towards the Acting armies during the first Winter march: "Our divisions always received the compassion of masses and their active help". In particular, the peasants of the village Oksanynno of Uman powiat guarded Ukrainian soldiers during the night rest and during the battle at Talne the peasants took the cannon from the enemies and delivered it on their own horses to the Ukrainian camp ${ }^{30}$.

Eventually, the commander drew a favorable conclusion: “...When the army got to the very heart of Ukraine, they saw the similarity of their ideology with the ideology of the rebels and peasant masses, they also felt that the people saw them as their weapon, apart from the name "petlurivtsi" (supporters of Petlura) they were also called "Ukrainians" and "our army"...",31.

However, Ukrainian peasants also took part in military formations that fought against Ukrainian statehood. It is important to reveal if they were in Worker-peasant Red army on the territory of Ukraine.

\footnotetext{
${ }^{27}$ Омелянович-Павленко М. Спогади командарма (1917-1920). С. 190.

28 Там само. С. 221.

${ }^{29}$ Капустянський М. Похід українських армій на Київ-Одесу в 1919 рочі. С. 90.

${ }^{30}$ Омелянович-Павленко М. Спогади командарма (1917-1920). С. 248.

31 Там само. С. 268.
} 
During the first Soviet-Ukrainian war some dismissed military divisions including Ukrainian peasants-soldiers joined the Bolshevik advance (divisions of the $7^{\text {th }}$ Army). However such participation was sporadic since the core majority of Red army consisted from ethnical Russians from other regions.

The Red Cossacks can be considered as the exception formed at the beginning of January 1918 in Kharkiv from initiative of V. Shakrai and V. Prymakov. Such a naming, as Prymakov later wrote, was accepted as an "opposition to Petlurian free Cossacks". The $1^{\text {st }}$ regiment of Red Cossacks was created on the basis of the $3 \mathrm{~d}$ battalion of the $2^{\text {nd }}$ Ukrainian spare regiment that took the side of Bolsheviks. However, the present materials testify that the majority of Red Cossacks were of worker, not peasant origin.

However, in 1919 the situation significantly changed. The occupational Red army had a peculiar hybrid content (like the modern Russian-terrorist military groups on the occupied part of Donbas). As M. Kapustianskyi: "In Soviet Ukrainian army there were the divisions formed in Ukraine and those that came from central Russia. The organization of both was not equal. During the formation of their divisions in Ukraine the Bolsheviks had to take into account the character of Ukrainian population - very active before partisan war and during operations in their groups with their ottomans" ${ }^{32}$.

The content of these Ukrainian formations was rather diverse. Among them there was the $1^{\text {st }}$ regiment of the Red Cossacks under the leadership of Vitaliy Prymakov that previously retreated to Russia, but continued to exist in the Red Army of RSFSR. Later it became the cavalry brigade, division and at the end of 1920 - the first cavalry corpse of the Red Cossacks. However, it included a lot of international groups (Hungarians, Kurds, Lithuanians, Kubans, etc). The $1^{\text {st }}$ Ukrainian Soviet army consisted from Ukrainian formations ( $1^{\text {st }}$ and $2^{\text {nd }}$ Ukrainian Soviet divisions - former "tarashchantsi" and "bozhenkivtsi"), as well as from Russian ones - the $3 \mathrm{~d}$ Border and the $9^{\text {th }}$ shooting division of RSChA.

We can judge if the ethnical content of these formally Ukrainian divisions corresponded to their naming from the memories of Vsevolod Petriv. The general-horunzhyi mentioned that $100 \%$ of Ukrainians from the Right bank and some Ukrainians from Slobidska Ukraine from "tarashchantsi" took the side of Bolsheviks.

But from reformation into the division they were joined by cannon groups of solely Russians from Saratov and Yufim govetnorates. Before the beginning of advance against the Directory citizens of Smolensk and

\footnotetext{
${ }^{32}$ Капустянський М. Похід українських армій на Київ-Одесу в 1919 роиі. С. 94.
} 
Voronezh governorate also joined them. The regiment of Zaliznyak was dismissed because of "chauvinist beliefs" and formed again on the basis of citizens from Smolensk and Volohod governorates.

"In 1919 when the Volyn group..., defeated "tarashchantsi" nearly 800 people from Bohuniv regiment and 120 from Honta regiment were captured. Bohun regiment had $40 \%$ of people that were from Tambov, $10 \%$ from Viatychi, 15\% from Moscow and 5\% were Kazan tatars, $10 \%$ were Belorusians and $20 \%$ from Slobozhanshchyna and Chernihiv regions, mostly from Starodub powiats, thus partially Russians. People from Honta regiment were from Tambov governorate"33. Thus, to establish the percentage of Ukrainian peasants in these divisions is rather difficult.

However, the rebellion formations consisted mostly from peasantry that due to different reasons left UPR army for the Red army.

At the end of December 1918, right after the victory of anti-Hetman rebellion, Dnipro division of ottoman Zelenyi (D. Terpyla) declared that it did not want to fight against the Bolsheviks Amidst the battle for Kyiv in January 1919 this division opened the front and hit the army of UPR between Kyiv and Kremenchuk, thus facilitating the occupation of the Left bank and Kyiv by Bolsheviks. Ottoman Zelenyi declared Soviet mottos and retreated to the forests of Trans-Dnipro area where he continued to implement the operations together with Bolsheviks or on their own. Only in May 1919 they recognized the authority of Directory.

One of the biggest peasant unions that took the side of Bolsheviks at the beginning of February 1919 was the 6thousand Kherson division of the Acting army of UPR under the command of Nykyphor Hryhoriev. It became the $1^{\text {st }}$ brigade of Zadniprovska Ukrainian Soviet division and then, in April 1919 it was reformatted into the $6^{\text {th }}$ Ukrainian Soviet division due to the draft in local powiats. Hryhoriev remained the commanding officer. The $1^{\text {st }}$ regiment of Red Cossacks that was in Lubny at that time joined the uprising of Hryhoriev.

However on May the $8^{\text {th }} 1919$ Hryhoriev issued Universal "To the people of Ukraine and the soldiers of Red army" where he called for the general uprising against the Bolshevik dictatorship in Ukraine and announced the goals of his struggle. He proclaimed himself as "Ottoman of partisans of Kherson and Tavria Hryhoriev". The forces of rebellion involved 15-23 thousand of combatants, predominantly the peasants. Obviously, this uprising was caused by the rise of social-political tension in the village, caused by the policy of "military communism" and the establishment of Bolshevik dictatorship. The actions of the

33 Петрів В. Військово-історичні прачі. Спомини. Збірник /вступ В. Сергійчука. Київ «Поліграфкнига», 2002. 640 с. 
rebellious divisions provoked the general peasant uprising against the Bolsheviks in Ukraine.

The issue of participation of Ukrainian peasants in formation of Military forces of the South of Russia still remains little researched. Mostly the people were drafted, but there were voluntary subdivisions, for example among the local self-defense units of the State Guard.

Apart from this, as S. Kornovenko claims, the Special council and the Government of the South of Russian led the pro-peasant agrarian policy (state protectionism of the peasantry), they cared about the improvement of the land management, increasing of technical cultivation of land, providing of land farms with equipment, seed funds, working cattle, prevented the escalation of confrontation in villages.

It could not but cause a positive treatment of peasants towards the Whites policy of normalization of rent relationships and intensification of agrarian sector as an economy branch ${ }^{34}$.

However the attempts of social consolidation were significantly undermined by the rebellion movement. M. Herasymenko noted that after the raid of Makhno army the peasant mass not only joined the opposition against the authority of Denikin, but also joined the armed struggle against $\mathrm{it}^{35}$.

\section{CONCLUSIONS}

Thus, the development of revolutionary events and the establishment of national statehood directly depended on opinions of Ukrainian peasantry and its military activity. However, the peasants as the military-political force had rather unstable convictions. As a rule, they greeted every new authority that promised to resolve the agrarian issue according to their interests, later they got disappointed in it and eventually rebelled against it.

Sociomental aspects of militarization of the peasants included the references to the "Cossack tradition" often interpreted as a "Cossack freedom". They tried to combine military craft with the traditional plowman work (at the first opportunity they returned to it). Military actions of the armed peasantry were mostly defensive (they defended their own homes). That is the source of the locality of peasant thinking, isolation of their "peasant world".

As for the military aspect, the peasants took part in voluntary formations and rebellion groups led by ottomans. The latter have special social and psychological characteristics. Not that many peasants took part

\footnotetext{
${ }^{34}$ Корновенко С.В. Аграрна політика урядів А. Денікіна та П. Врангеля (1919-1920 рр.). дис. ... д-р. іст. наук. Київ 2009. С. 389-390.

${ }^{35}$ Герасименко Н.В. Батько Махно. Мемуары белогвардеййа / Под ред. П.Е. Щеголева. Москва Ленинград: Государственное издательство, 1928.
} 
in the regular formations of peasants. Big peasant military formations were not stable. After they faced with organized resistance of the opponent, they, as a rule, dispersed into little groups and resorted to the partisan tactics of struggle.

Military peculiarities of the new revolutionary peasants correlated with their statehood principles. Their support of ottomans was caused by their reluctance to the new authority. After all, the state elements in the consciousness of the majority of peasants were rather weak.

\section{SUMMARY}

The article analyzes the peculiarities of militarization of Ukrainian peasantry as the part of its emancipation in the process of militarization. It argues about its significance during the events of the World War I. The war caused the drastic transformation of the peasant outlook that integrated the remains of the warfare.

It claims that the role, social status and behavior of the "peasant with the gun" changed with the beginning of the revolution of 1917. An armed peasant became an important political factor of the deployment of the revolutionary events. On the one hand, the important part of the peasants joined the process of the "expropriation of expropriators" - expropriation of the lands and the estate.

On the other hand, the peasant environment launched the voluntary movement of self-defense (The Free Cossacks) from internal chaos and external dangers. Eventually, the militarization of the peasantry determined its leading role in the events of Ukrainian revolution 1917-1921, including the deployment of the rebellion movement, peasant war, ottoman movement etc. The article reveals the peculiarities of the peasants' participation in military formations of the revolutionary period - the Acting army of the UPR, Worker-peasant of the Red army, The military forces of the South of Russia.

\section{REFERENCES}

1. Авраменко Н. Спомини запорожия: Документальне видання. Київ: Темпора, 2007. 456 с.

2. Верстюк В. Махновщина: Селянський повстанський рух на Україні (1918-1921). Київ: Наукова думка, 1991. 368 с.

3. Вишнівський О. Повстанський рух i Отаманія. Збірник. Дітройт; Мічіген: Капітула відзнаки хреста залізного стрільця, 1973. 109 c. 
4. Герасименко Н.В. Батько Махно. Мемуары белогвардейцуа / Под ред. П.Е. Щеголева. Москва-Ленинград: Государственное издательство, 1928. 115 с.

5. Капустянський М. Похід українських армій на Київ-Одесу в 1919 роиі [в] Украӥна 1919 рік: М. Капустянський " Похід українських армій на Київ-Одесу в 1919 роиіі”. С. Маланюк "Уривки зі спогадів”. Документи та матеріали. Документально-наукове видання / Передм. Я. Тинченко. Київ : Темпора, 2004. С. 59-286.

6. Корновенко С.В. Аграрна політика урядів А. Денікіна та П. Врангеля (1919-1920 рр.). Дис. ... д-p. іст. наук. Київ: Інститут історії України НАН України, 2009. 474 с.

7. Кульчицький Ю. Шаблі з плугів : Український повстанський pyx y визвольних змаганнях [1917-1926 pp.]. Львів : Ін-т українознавства ім. І. Крип'якевича НАН України, 2000. 260 с.

8. Куренышев А.А. Крестьянские военно-политические организаџии России. Повстанчество. 1918-1922 г2. Москва 2010. 171 с.

9. Лободаєв В. Участь Вільного козацтва в селянському повстанському русі (травень - серпень 1918 р.). Вісник Прикарпатського університету. Історія. 2011. Вип. 20. С. 70-78.

10. Лозовий В. Солдати і дестабілізація суспільно-політичного становищ а: вплив Першої світової війни на революційні процеси в Україні (1917р.). Вісник Київського наџіонального університету імені Тараса Шевченка. Історія. 2014. № 3 (121). С. 21-24.

11. Махно Н. Воспоминания. Кн.1. Русская револющия на Украине (от марта 1917 г. по апрель 1918 год). Париж 1929. 214 с.

12. Омелянович-Павленко М. Спогади командарма (1917-1920): Документально-художне видання / Упоряд.: М. Ковальчук. Київ: Темпора, 2007. 608 с.

13. Петрів В. Військово-історичні праиі. Спомини. Збірник / вступ В. Сергійчука. Київ : “Поліграфкнига", 2002. 640 с.

14. Поршнева О.С. Крестьяне, рабочие и солдаты России накануне и в годы Первой мировой войны. Москва : РОССПЭН, 2004. $365 \mathrm{c}$.

15. Поршнева О.С. Менталитет и сочиальное поведение рабочих, крестьян и солдат России в годы Первой мировой войны (1914 март 1918). Дисс. ... д-р ист. наук. Екатеринбург, 2000. 359 с.

16. Русское крестьянство и Первая мировая война : международный круглый стол / публ. П.П. Марчени, С.Ю. Разина. Новый исторический вестник. 2014. № 2 (40). С. 8-89.

17. Тютюнник Ю. Революційна стихія. Дзвін. 1991. № 8. C. 92-107. 
18. Удовиченко О. Україна у війні за державність. Історія організачії $і$ бойових дій Украӥнських збройних сил 1917-1921 рр. Вінніпег: Видав хорунжий УСС Дмитро Микитюк, 1954. 179 с.

19. Щербатюк В.M. Звенигородське збройне повстання. Краєзнавство Черкащини. Черкаси, 2005. Вип. 8. С. 136-149.

20. Щербатюк В.М. Селянський повстанський рух в Украйні 1917-1921 років: українська історіографія : автореф. дис. ... д-ра icm. наук 07.00.06. Київ : Київський нац. ун-т ім. Т.Г. Шевченка, $2013.36 \mathrm{c}$.

\section{Information about the author:} Masnenko V. V. Doctor of Historical Sciences, Professor, Head at the Department of History Ukraine, Bohdan Khmelnytsky National University of Cherkasy 81, T. Shevchenka str., Cherkasy, 18031, Ukraine 